\title{
Integrating Multiliteracies for Preservice Teachers Using Project-Based Learning
}

\author{
Terry Sefton \\ University of Windsor \\ Kara Smith \\ University of Windsor; University of the Highlands and Islands \\ Wayne Tousignant \\ University of Windsor
}

\begin{abstract}
Using a project-based learning approach, three teacher educators, teaching three different methodology courses, worked together to create, plan, and assess an arts-based assignment completed by preservice candidates. The preservice teachers created an animation project while applying curriculum expectations in three subject areas: visual arts, music, and language arts. The three subjects were segregated for the purpose of instruction, integrated during the group work and creative process, and then jointly assessed using negotiated reporting. This paper describes the project and details the challenges of integrating teaching and learning across institutionally segregated courses when student expectations are conditioned by their prior experience of siloed, subject-based learning, and discusses lessons learned by the three teacher educators and implications for team teaching across the curriculum.
\end{abstract}

\section{Introduction}

This paper will describe a project-based assignment completed by preservice teachers at a faculty of education in Ontario. We the authors are three teacher educators, teaching language arts, visual arts, and music. In 2010-2011 we arranged with our administrators to teach the same cohort of Primary/Junior preservice teachers. We worked together to plan an integrated assignment that 
would bridge each of the separate methodology courses and would culminate in an animation project. The students worked in groups, and their final projects were evaluated through negotiated reporting, a process that uses self-reporting, peer review, and instructor assessment (Falchikov, 2013).

The ensuing period was one of major change in Ontario. As part of the election platform in 2011, the Liberal party promised to lengthen teacher education. In 2013, the provincial government announced that all faculties of education would move from a one-year to a two-year Bachelor of Education program, starting in 2015. The institutional upheaval of quickly transitioning all of our courses, while responding to enrolment constraints which reduced our student body by more than half, mitigated against further cross-curricular teaching. Nevertheless, in the years that followed, each of the authors continued to include various integrated activities in our courses. This paper will identify some of the challenges of integrating teaching and learning across institutionally segregated courses, will consider some of the implications for instructor teaching as well as for student learning, and will reflect on the effects this collaborative teaching project had on our own pedagogy. For the purpose of this paper, the term preservice teacher refers to a student in the Bachelor of Education program. They may also be referred to as students in the context of their classroom learning.

\section{Project-Based Learning and Literacy}

During the process of project-based learning (PBL), one or more students identify a question or problem or topic and then work to build their knowledge and skills to create a product, which might be a report or an artefact or a performance. PBL is rarely subject-specific. There may be many lessons learned in many diverse fields involved concurrently, while the student(s) research(es) the question and build(s) their project (Baydar, 2018; Bell, 2010; Munakata, 2015). Even when production is focused on one subject, project-based learning is multidisciplinary. One cannot take an external task, for example, and categorize it as "math" or "language" or "drama." PBL is often approached as a group activity, as the diverse demands of PBL benefits from multiple collaborators who bring different aptitudes and skills to the project. The project, and how a group attacks it to plan and problem solve, may draw from any number of different knowledges, modalities, and literacies. Project-based learning also demands creativity, as students are encouraged to define their own interests, set their own goals, and create paths and strategies to complete the project to their own satisfaction, rather than to some externally dictated criteria of success for evaluation (Baydar 2018; Bell, 2010). While creativity is often assumed to be the prerogative of the arts, any area of knowledge or discovery, when explored through PBL, involves creativity (Munakata, 2015). Project-based learning, when used with the arts curriculum, carries all the power of student-centered learning as well as the distinctive creative potential of each art medium. The arts, for the purposes of this paper, are defined, as they are in the Ontario Ministry of Education (2010) curriculum, as visual art, music, drama, and dance. Each of them constitutes a form of literacy, and all of them are forms of communication built upon the principles of 21st century literacy where aural, visual and digital overlap (Holloway, 2012, New Media Consortium, 
2005). Thought of in this way, by doing art or doing music, teachers and their students are doing literacy.

The Ontario curriculum stresses language across the curriculum, which assumes that English is everywhere (Ontario Ministry of Education, 2006). Teachers can teach language arts curriculum through the arts; and each of the arts are most often taught while also using spoken and written language as a means of communication and collaboration (Gallagher, 2010). There is not a single art where language, loosely defined, is not threaded through. Multimodal literacy, the ability to make meaning from multiple modes of expression, has exceeded the scope of singular literacies for 21st century skills (Gude, 2007; Mills \& Unsworth, 2018; Sullivan, 2002; Tousignant, 2008). As Mills and Unsworth (2018) state, "communication from birth to adulthood is fundamentally multimodal" (p. 618). An added benefit of working with multiliteracies in the classroom is to encourage students to work from their individual strengths while opening up to other ways of learning and communicating. It allows "learners to have agency in the content and modalities with which they choose to innovate or to critique" (Holloway, 2012, p. 158).

\section{Institutional Context and Transdisciplinary Approaches}

In Ontario, initial teacher education programs are relatively short. A student who has previously completed an undergraduate degree may enroll in a Bachelor of Education program, where they will take 60 credits over four terms and spend 80 days in the field2. Education programs in Ontario prior to 2015 were even shorter: an eight-month professional program that alternated university courses and school teaching placements (practicum). Most of the preservice teachers' prior experiences in school (kindergarten to university) have been in an institutional system of segregated subjects. That siloed approach often continues to be their experience in Bachelor of Education programs, where they take subject-based methodology courses. Therefore, it should not be a surprise that many of our students find it difficult to apply and teach through an integrated, multidisciplinary method, as they have never seen it modelled. Multidisciplinary or transdisciplinary learning is an approach which nurtures innovation (Drake, 1998; Drake \& Burns, 2004; Henriksen, 2018). Foucault, in The Archaeology of Knowledge (1969), saw different discourses as playing across each other, and creating potentials for meaning making that were not possible when thinking was contained within the self-regulation of a single discourse (Dosse, 1997). Blurring the boundaries of subject areas and encouraging preservice teachers to teach across disciplines or curricula builds the capacity to think critically and creatively, and to concurrently apply multiple subject-specific skills.

Transdisciplinary work encourages learners to use and demonstrate stages of thinking and creativity. Henriksen (2018) identifies seven distinct stages to transdisciplinary projects: "observing; patterning; abstracting; embodied thinking; modeling; play; synthesis" (p. 2). Each of

1 Professionals in the field may go on to take a Master of Education, or Additional Qualification courses that are offered through faculties of education. Such courses are required for positions in leadership and specialization.

2 This describes the requirements for a 'consecutive' program. Some faculties in Ontario offer 'concurrent' programs, which combine an undergraduate degree and a Bachelor of Education degree over a period of five or six years 
these is relevant to project-based learning, but the element that most resonates with integrating and working in the arts is play. Henriksen defines play as:

something that we do just "for the fun of it." It may involve creating new rules or breaking the existing ones of established procedures. Simply put, "play" is using knowledge, body, mind and abilities for the pure enjoyment of using them. When imaginative or innovative people play with things or concepts or processes, they may open doors to new ways of thinking via unexpected breakthroughs. Creative people in different disciplines all speak to the value of play. They play with distinctions, boundaries, unassailable truths and the limits of utility. Through this play they transform ideas into creative acts or new knowledge. (Henriksen, 2018, p. 3)

There is a tension between what may be seen as "for the fun of it" and activity that may challenge "boundaries, unassailable truths" (Henriksen, 2018, p. 3). As Diane Ackerman (1999) points out, play is serious business, and may lead to personal transformation.

Our students were enrolled in the Primary/Junior division of the Bachelor of Education program. Their undergraduate degrees were from many disciplines, but they were not expected to be specialists; rather, they were training to become generalists, who might be expected to teach all the subjects at the elementary level (grades 1-8). Most of them did not have a design-based or artsbased learning background. Thus, The Animation Project exposed them to multiple disciplines as well as multiple literacies and challenged them to identify their own gaps and to acquire the skills and resources to complete the project. Working in a group, each student was responsible for part of the process, and for negotiating and navigating with their peers.

\section{The Project}

Learning content through the arts is a fluid integration of material practices and processes. Each art follows similar processes of creation: brainstorming, organizing, drafting, editing and revising, and exhibiting or performing, with constant peer and teacher anecdotal feedback throughout the process. Figure 1, for example, illustrates the creative process for language arts.

Although the arts may produce objects, they are not object-bound. The art object, artefact, or performance provides a focus or an excuse for creative action. It also maintains significance as a sign in a field of signs, as a metaphor for meaning that eludes the easy grasp of language (Van Leeuwen \& Jewitt, 2001). In the performing arts — drama, music, dance, and performance art — the product is time-based and hence transitory; even when captured on video, it is a single iteration of a performance, which is by nature organic, not fixed. There is no right answer, or perfect outcome. The lack of a predetermined outcome, or of highly defined criteria of success, can be experienced by students as confusing or risky.

How do we, as teacher educators, provide a framework for integrated learning for new teachers who have never experienced multidisciplinary or transdisciplinary learning? Or who may be fearful of taking risks in creative work? Working from our own philosophical and pedagogical perspectives, we model it. 


\section{Evolution of the Project through Language Arts}

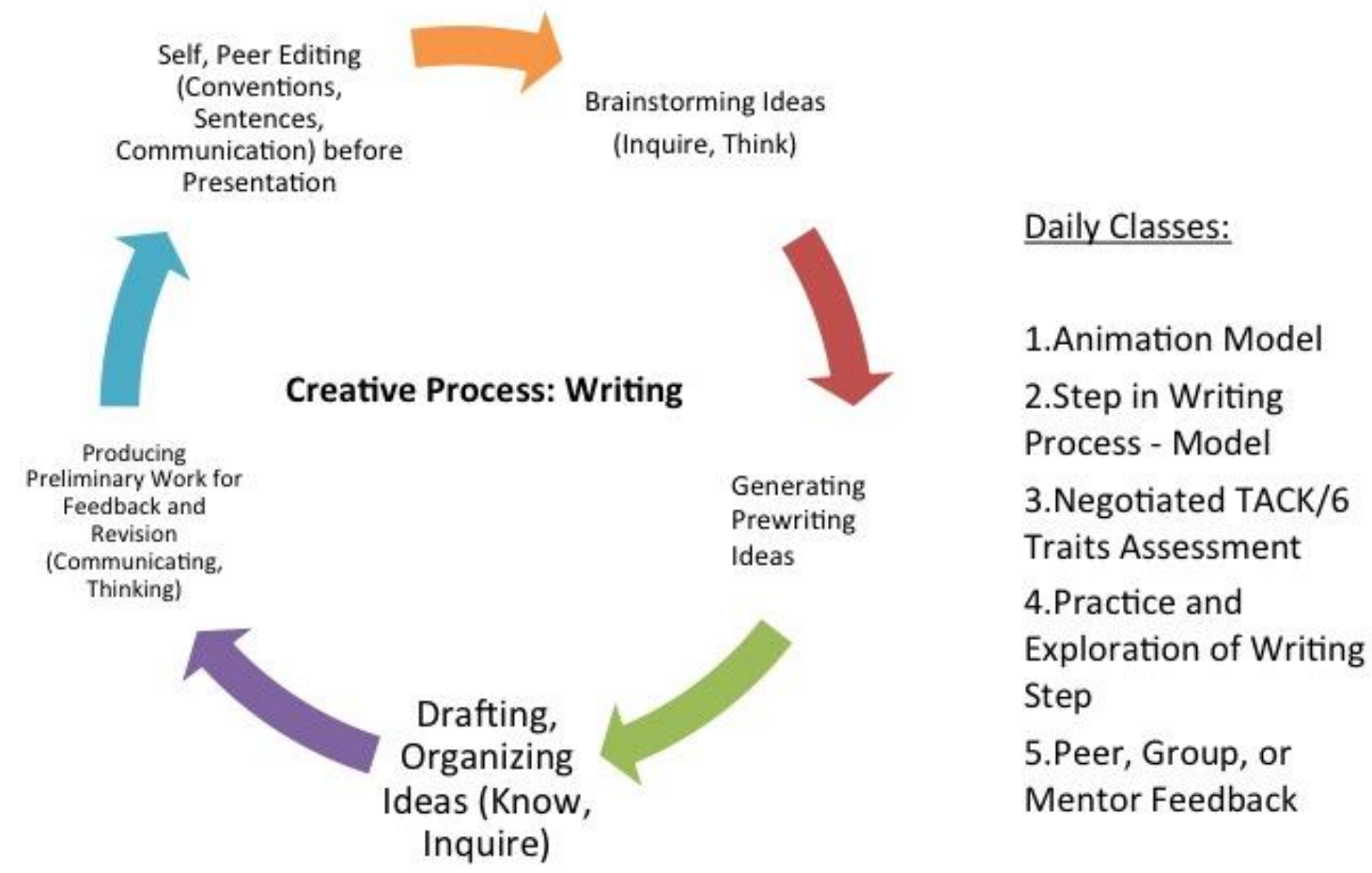

Figure 1: Language Arts Project: Creative Process.

Multidisciplinary learning requires a cast of participants with a shared vision. Here are brief biographical profiles of the three principle actors (instructors) in this teacher education project:

1. Wayne Tousignant. Visual arts educator, internationally recognized sculptor and multimedia artist. Wayne has collaborated with Terry and Kara on several integrated arts projects. Wayne's focus is on the creative process: shaping, developing, and changing a skill through feedback and exhibition. His goal has always been to give teacher candidates the ability to make meaning from multiple modes of expression (Tousignant, Stanley, Salinitri, \& Smith, 2011).

2. Terry Sefton. Music arts educator, professional cellist, and artist. Terry's passion for teaching through the arts is infectious. When we began to conceive of this joint intervention, Terry was a natural partner. Her way into learning and story is through song, and the strong ties between voice and identity. Performance takes on a double meaning in 
music, as the musician, professional or amateur, teacher or student, must enter into risk and exposure of self in the act of performing (Sefton \& Bayley, 2013).

3. Kara Smith. Language arts educator best known for her work integrating novel study through content-based courses, and for her creative writing as a poet. Kara has worked with collaborators nationally and internationally, in artist residencies (Smith, 2017).

Our goal was to combine the basic curriculum content, knowledge, and pedagogical skills training in our three courses while using a transdisciplinary approach. In practical terms, we wanted to provide new teachers with a fluid model of how to teach basic reading, writing, media, art, and music through one holistic project, using project-based learning. Technology has been identified as a necessary interdisciplinary skill (Ontario Ministry of Education, 2006), so we also wanted to include digital applications in the project. Keeping in mind the early and influential animation work that John Grierson created for the National Film Board of Canada (John Grierson and the NFB, 1984), we decided to use an animation project as the central focus. Each of the educational disciplines of teaching and assessing in each of the core disciplines would be embedded within the project. The outcome would (we hoped) model and mirror a lived, multidisciplinary classroom. In transdisciplinary work (Drake, 1998; Drake \& Burns, 2004), the learning begins from real life; the disciplines, non-constructed, are embedded and learned through the real-life experiences.

Our project was a little different than any of us had done before. We planned our year-long course outlines with an animation project in mind. How the student groups would design their animation, what story they might tell, how they would integrate music into the final project, were up to the students; but the concept of an interdisciplinary, creative, project-based approach, and the outcome of an animation project, was planned as a group assignment into each of our courses.

We used the model of the creative process (Ontario Ministry of Education, 2010) as the underlying structure and the theoretical framework. This cyclical model is found in all of our disciplines - in visual arts, music, and language arts. Each of us used this model as we introduced the animation project to our students. As our courses progressed, we received ongoing anecdotal feedback from each other as teacher-partners and from our students.

\section{Project-Based Learning}

The preservice teachers who participated in the project were all simultaneously enrolled in Wayne's visual arts' classes, Terry's music classes, and Kara's language classes, with multiple sections in each of the courses. Students formed collaborative work groups with four to six members. Each group would create an animation project by the end of the year. Additional activities in each course fed into the animation project, including model lessons (microteaching) in all three courses. 
In the Language Arts Methodology course, the creative process of animation storyboarding was first experienced through a primary reading, writing, and assessment activity: "How to write a story" and "How to teach how to write a story (non-fiction or fiction)." The preservice teachers first experienced a modelled lesson, either in the role of teacher or student, then developed their own writing skills which they were able to apply to their central animation project.

During in the fall term, the class focused on the reading and media strands of the Ontario language arts curriculum (2006). Students explored the different types of texts seen across grades 1-6. The reading samples which the instructor chose were all animation storyboards (from graphic novels made into film) and included persuasive, narrative, and informational writing crossing different cultures and languages. The students learned how to teach and assess different reading texts through shared, guided, and independent reading modules. They also experienced how to construct a TACK (Thinking, Application, Communication, and Knowledge) assessment for each reading module. In this way, they experienced, firsthand, as learners and teachers, how content learning and reading assessment (i.e., diagnostic reading assessments and reading inventories) can be embedded within one multidisciplinary project such as animation.

Concurrently, in Visual Arts Methodology, the fall term focused on skill building activities such as gesture drawing, cartooning, print making, and painting — design fundamentals that could be used in the construction of characters for an animation. Open-ended constructivist projects, such as Picasso faces modelled teamwork and ongoing daily peer feedback. By the winter term, students were working with technology, using computer applications to create, draw, and animate characters, and building a repertoire of story-telling skills while using animation techniques.

The fall term in the Music Methodology course was focused on building a foundation of musical content knowledge and introducing performance experience for students who may not have any or much prior musical experience. Therefore, Terry began the music course in the fall term with safe group activities, learning songs by rote and using drums, as a gentle entry into performance. These musical activities helped students to build confidence, and to develop skills that would be needed later for the animations project. By second term, the students had gained sufficient knowledge and skills to be performing on instruments and composing using computer software. The students were also required to create a lesson plan that used both music and one other arts strand. For this assignment, they were encouraged to design a lesson that would be part of their animation project.

One other assignment completed in the Music Methodology course which may have contributed to the students' awareness and strategies for curriculum integration was the bulletin board project. Week by week throughout the school year, groups of students had to design and create a bulletin board and install it in the public hallway outside the music classroom. The bulletin board had to support music curriculum applications in the classroom, while using visual and symbolic strategies of communication. Many of the preservice teachers integrated music with other curriculum strands, such as language arts, visual art, or social studies, for example. The assignment required them to create a map of the bulletin board and revise or modify the bulletin board for their music portfolio. Most of the students made the connection between this task and the animation project, between mapping and storyboarding. 
Students who included music as an integral part of their animation projects brought that interest and excitement into music class; they asked to book rehearsal space, to borrow instruments, and called on Terry for her input. During the bulletin board assignment in Music Methodology, all of the students applied skills and knowledge from Wayne's visual arts course to plan and create an effective design, and many went to Wayne for materials and advice. The interdisciplinary activity from the three centrally focused classes made the development of their animations richer and deepened their learning experience, as became evident from student comments collected at the end of the course.

\section{Instructors as Models}

A central component of the project was the deliberate modelling of the creative group process for the preservice teachers. To facilitate this, each professor participated in one or two of the other classes. Terry, for example, viewed the drawings that students were creating for Visual Arts Methodology at an early stage of the creative process, and provided comments; she gave advice on adding music afterwards, post-production during the editing stage, versus integrating music at the start of the project, in the planning stage. In addition, Terry visited the Language Arts Methodology classroom to take part in looking at exemplars and in interpreting the creative process behind the exemplars, and in suggesting strategies for student projects. Kara joined Wayne during two visual arts classes to experience drawing characters and working with various materials for animation. As well, Wayne sat in on Kara's language classes to model peer feedback and brainstorming in the early part of the creative process. Finally, at the end of the project, Terry joined both Wayne and Kara in viewing the animations after they were submitted, and in provided feedback to the students as part of the negotiated reporting approach.

\section{Student Feedback and Lessons Learned}

The students received daily feedback from peers and instructors on the three artistic components of their animation projects. In addition, midway through the project and near the end of the fall term, the students did a gallery walk of all of the projects. Groups set up the storyboards, designs, sound, and in some cases, preliminary film animation, of their projects. The students then walked around the classroom and added post-it notes to the various projects, with comments and suggestions. This provided a strategy which some groups continued to use to assess and monitor their progress on the project.

Prior to the gallery walk, students had been grumbling about the subjective nature of assessment in the arts. During the walk, many students recognized that some of their peers' projects were objectively stronger than others - that is, as individuals they could recognize and as groups of peers they could agree with a comparative evaluation of the works. After the gallery walk, the students were more motivated to learn the skills necessary for putting the cartoons and frames into film, and for revising their projects. For example, students now asked Wayne for help with backdrops, cameras, and setup. They started to make the connection between cartooning, 
foreground/background (in Visual Arts Methodology), and their animation storyboards in Language Arts Methodology; and they saw the importance of music and sound to the overall effect.

Some of the comments the professors received about the gallery walk part of the process on peer work motivation were as follows:

"I now realize how powerful song, music, voice can be with the piece. It's everything."

"I want to find a good song, music to go with this now..."

"I really need to add 'catchy music' now"

"I want to know how to make scenes/transitions between slides go smoother"

"I want to know how to get the timing right so it doesn't look choppy, so that the story flows better"

"I need to crop my pictures and add more facial expressions" (Anonymous student comments)

Seeing their initial designs on the screen in front of their classmates engaged the students in the visual-technical side of the creation. This feedback allowed them to see the integration of the elements, and to recognize the importance of blending the three modalities (visual art, music, and text) with technology. The feedback spurred them to go back and revise their own project, and to continue to develop it to a higher standard.

In addition to the daily and end of term feedback for the students on their animation projects, the professors sought feedback from the preservice teachers regarding their experiences in the integration project. Since feedback was such a common, habitual occurrence in the classes, as a part of the creative process and idea generation in each of their assignments, the students had become confident and articulate in providing honest and helpful feedback.

During the fall term and the introduction of the animation project, many of the students commented that they couldn't see how the visual arts, music, and language arts were interrelated. One student commented, "music doesn't seem to be involved at all!" Others commented, "I just want to do practical things that I can go into a class and actually use," and "I just want to know how to teach reading. I don't want to have to do all this other stuff!" Some teacher candidates wanted to use Bitstrips (a software program that automatically generates images) because they were afraid of cartooning and drawing and were more at ease with the technology (having the computer produce it for them even if it took more time). The general mood was not encouraging! The gallery walk at the end of term proved to be a turning point for many.

By second term, after the students had been working on their group animations for a while, some of them were worried about being able to produce three minutes of animation on film. The goal seemed too large for them. Also, during second term, preservice teachers would often be preparing for school board interviews for coveted teaching positions. With interviews looming, some students commented:

"Why do we need to do this animation? I was at the TDSB for a job interview last week and they asked me questions about 'balanced literacy' that I could have used more than animation." 
"This is really time consuming and I don't even see what it has to do with literacy!" (Anonymous student comments)

Understandably, their focus was on applying for a teaching job, and on what they perceived to be the most important skills needed to get the job. Our teaching goals as professors in a faculty of education may not be job focused, despite the fact that we teach in a professional degree program; our goal is more often on creating critical thinking skills in our students and in modelling innovative pedagogies for them in the classroom, so that they may continue to grow as educators throughout their career. On a metacognitive level, there has to be the ability to recognize bothwhat are current teaching practices in primary and secondary school, and part of the most soughtafter hiring profile, and what is being explored and modelled as pedagogical innovation in the university setting. Both professors and preservice teachers should, ideally, have the ability to recognize these contrasting demands, and be capable of learning and growing from them.

Occasionally, comments uncovered the different perceptions of the professors as well. For example, one preservice teacher stated, "I did the music integration lesson and when I emailed it to Terry, she said, 'Language Arts isn't really an art,' so I had to re-do the whole thing." 3 This exchange exposes some tension between different subject areas, specifically a core subject such as language and an arts subject such as music or visual art. The student may not know that the arts are a multiple subject field in the Ontario Ministry of Education's curriculum with four distinct strands and grade-by-grade curriculum expectations for each. Professors who teach in the arts may respond to such questions in a protective or reactive way since an arts subject is often accorded half as many hours (or even less) in university education programs as language arts or math. Terry's response illustrates some of that frustration for arts education professors, in trying to protect the distinctive territory of the arts. Wayne was equally insistent that about not referring to the arts. "It's not plural," he stated, "There is no such thing as 'the arts.' There is Visual Art, there is Music, there is Dance. Each is a single subject with its own curriculum." He felt that the Ontario Ministry of Education, in putting all four fields into the same curriculum document, contributed to diminishing the importance of each as a distinctive discipline. Kara, while teaching a course in language arts, often included elements of the drama curriculum in her teaching; and Kara is a published poet, surely an art form as much as a literary form. So, it's not surprising that the students found these boundaries confusing and chafed at what they sometimes saw as an arbitrary nicety of language.

As well as the critical feedback from the preservice teachers, we also had concerns about troubling aspects that emerged during the project. Copyright infringement, for example, was an issue that frequently arose. Preservice teachers needed to be aware of copyright law and the protections for intellectual property of artists, musicians, and writers; but even within the group animation projects, sometimes the lines were blurred. How much of a song can be used as an introduction? What if an animated Bitstrips character is used rather than one that is self-drawn?

3 Terry's comment to the student had been regarding the government's curriculum document in music: "Language Arts, despite the inclusion of the word 'arts', is not part of the Arts curriculum - The Ontario Arts (2009) curriculum includes just four strands: Dance, Drama, Music, and Visual Art.” 
What if a story is too closely related to another? And, what is cultural appropriation? Why does it matter? As an educational exercise, it raised some wonderful debates, but sometimes contributed, again, to student confusion and discomfort.

Evaluation was another contentious issue. Preservice teachers would be receiving separate marks on their university transcripts for: Visual Arts Methodology, Musical Arts Methodology, and Language Arts Methodology. Students complained that they were confused about how the animation project would be included in their course mark. This was, in part, because each of the instructors had included it in our course assignments and expectations in different ways, folding elements of the animation project into other assignments. Knowing how marks were calculated in each class would have eased the students' marks anxiety. Because a numerical grade needed to be awarded for the class to fulfil the requirements for degree audit and GPA calculation, this was the one area of the integrated arts project that was most problematic. We the instructors had conceptualized it as one, integrated project, taught through a holistic lens. However, the university views courses as distinct and segregated, not whole and working together. An additional concern for the instructors was that a student's grade can be linked to their course evaluation (i.e., how the student evaluates the professor), and this could negatively affect promotion, tenure, and retention for two of the instructors, one of whom was untenured and one of whom was part-time.

Despite some critical feedback, many students' comments were positive. The benefit most often identified by the students as a result of the integrated animation project was subject confidence. Students stated that by being kinaesthetically engaged in the integrated learning, they were more conscious of the individual subject lessons built into a group project. The following student comments are illustrative:

The part of the lesson plan requirements that I found most helpful was having to integrate another Art into our music lesson. Using the curriculum document, I integrated visual arts into the lesson, and was able to reflect upon how we can create cross curricular lesson plans. I found this part a bit challenging, however, because in the past, and during my practice teaching experiences, I usually combined language arts and music, or language arts, and visual art, and so forth. This assignment, therefore, forced me to step out of my comfort zone, which I think at the time was difficult, but in the long run I think I definitely benefited from having to do that. (Primary/Junior Preservice Teacher)

Of all of the courses that were required of us at the Faculty of Education, the one I was most worried about was in fact this course on Music and Music Methods. I am a person that has very little experience with music as I felt I was never quite good enough at it in my younger days. I used to think that some people 'got' music while others just did not. I felt like an outsider within the world of music, never quite comfortable or wanting to hang around in that world for too long. During my very first class however I realized things were going to be different. The professor attempted to begin where we were as individuals and did not expect us to be professionals. She began singing songs that were familiar to us and introduced us to technical terms such as beat, tempo and rhythm through experimentation. It was at this point that I realized part of my music anxiety was due to poor teaching 
practices that did the opposite of these things. Maybe I could teach music after all. (Primary/Junior Preservice Teacher)

That so many of the preservice teachers had a positive response to questions about confidence by the end of the year is a testament to the power of integrated, project-based learning; but it is also a measure of how big a deficit many preservice teachers and teachers face in the arts. Without confidence, and with little governmental or school board support in the arts, it is little wonder that many classroom teachers avoid teaching the arts or provide minimal instruction or class time for the arts (Sefton \& Bayley, 2010). That is one reason why integrated, project-based learning is so effective. By building lessons from all subjects into the creative production of a group's design, every subject is covered in an authentic, meaningful way.

\section{Conclusion}

One advantage of combining visual arts, music, drama, and dance, along with language arts and media, is that preservice teachers can work from areas of confidence and strength. Project-based learning allows students and their peers to embark on complex projects that allow for individual choice and group interaction. Some of the students were concerned that their peers could hide behind or coast on the efforts of others; however, the open-ended goals of creative pedagogy are less concerned with measuring achievement, and more focused on process and transformation (Eisner, 2002). Preservice teachers who choose not to engage, or to engage fitfully or superficially, ultimately limit their own benefit or the likelihood of experiencing transformation. Those who did dedicate the time and effort, found that the rewards were more than merely marks for a course credit. For them, the activity became autotelic_-providing an experience "that is an end in itself" (Csikszentmihalyi, 1996).

This collaborative teaching project took place in 2010-2011. In the years that followed, there were a number of lasting effects. First, negatively, there was fall out for two of the instructors who did not have tenure during this period and were affected during their subsequent performance reviews by the results of an institutional Student Evaluation of Teaching (SET). A comparison of SET scores of the year before the integration project, the year of, and the year after, showed a distinct drop of student satisfaction for the year of the project. Factors that may have contributed to the students' dissatisfaction could include course content that students did not consider relevant; assessment criteria that, in students perception, were not clear enough; and other factors that are not visible from the standardized nature of the SET forms, such as a student's attitude toward taking risks, or lack of confidence and prior experiences in the arts. There is a risk inherent in trying new pedagogies and disrupting student expectations. Regardless of the immediate effect on SET scores, the student feedback did provide important information to instructors. Terry returned to a number of these ideas in projects in subsequent years, but made changes to the assignment, such as including more success criteria for students, showing exemplars of prior students' works to her classes, and including more stages of formative assessment along the way. Even so, the challenge of teaching in the creative arts and working without highly defined goals (which are 
antithetical to creative activity), will always involve some risk, not only to students but to instructors, as well (Elkins, 2001; Finn, 2015; Sefton \& Bayley, 2013).

When Ontario brought in a two-year Bachelor of Education program to replace the oneyear program, and the arts had to fight to maintain a foothold in the program. The topic of how the arts were dealing with these institutional pressures has been addressed in multiple conferences and symposia, including Ontario Ministry of Education Forums, an annual gathering of faculty of education instructors and ministry officials. As one of the changes to our Faculty of Education program, Terry developed Pedagogy of the Arts, a course for the two-year Bachelor of Education program that would bridge all of the arts. The course was eventually expanded to all Junior/Intermediate and Intermediate/Senior preservice teachers. The integrated animation project was a key element of the course design, and even with different instructors it continues to this day. So, while it may be a decade since we three authors first initialed this project, the ripples continue to affect our programming and our pedagogy. Unfortunately, the logistics of creating this model again are daunting. Scheduling of courses, so that three instructors who wish to combine their course content and assignments would be teaching the same cohort of students, would be very difficult, if not impossible, given the increased complexity of the 2-year Bachelor of Education program. However, integration can still occur informally, especially when teacher educators plan it into their course objectives. For example, students who are working on the Pedagogy of the Arts final projects go to their different methodology instructors for advice or resources or skills.

For our integrated animation project, we three instructors embedded one joint project into each of our courses. Our practical goal was to model cross-curricular teaching, and to give our students an opportunity for team planning, collaborative teaching, multimodal learning, projectbased learning, and arts-based research. On a more theoretical level, we hoped to encourage creative ways of thinking, to promote autonomy and agency, and to challenge students to take risks through transformative play. We also wanted to challenge ourselves to teach differently, by stepping outside of our disciplinary silos, and by connecting with our colleagues. Did it work? Yes. It did.

\section{References}

Ackerman, D. (1999). Deep play. New York, NY: Vintage.

Baydar, S. N., \& Sayilgan, O. (2018). A project-based learning process in art and design education: "Tell your fairytale, let it become a book." Idil Sanat Ve Dil Dergisi, 7(42), 145-150. https://doi.org/10.7816/idil-07-42-05

Bell, Stephanie (2010). Project-based learning for the 21st century: Skills for the future. The Clearing House: A Journal of Educational Strategies, Issues and Ideas, 83(2), 39-43. https://doi.org/10.1080/00098650903505415

Cornett, C. E. (1999). The arts as meaning makers: Integrating literature and the arts throughout the curriculum. Upper Saddle River, NJ: Prentice-Hall.

Csikszentmihalyi, M. (1996). Creativity: The psychology of discovery and invention. New York, NY: HarperCollins. 
Drake, S M. (1998). Creating integrated curriculum: Proven ways to increase student learning. Thousand Oaks, CA: Corwin Press.

Drake, S. M., \& Burns, R. C. (2004). Meeting standards through integrated curriculum. Alexandria, VA: Association for Supervision and Curriculum Development. Retrieved from http://www.ascd.org/publications/books/103011.aspx

Dosse, F. (1997). The history of structuralism. Minneapolis, MN: University of Minnesota Press.

Eisner, E., (2002). The arts and the creation of mind. New Haven, CT: Yale University Press.

Elkins, J. (2001). Why art cannot be taught: A handbook for art students. Champaign, IL: University of Illinois Press.

Erikson, J. (1995). The fate of the object: From modern object to postmodern sign in performance, art, and poetry. Ann Arbor, MI: University of Michigan Press.

Falchikov, N. (2015). Improving assessment through student involvement: Practical solutions for aiding learning in higher and further education. London, UK: Routledge.

Feldman, E. B. (1970). Becoming human through art: Aesthetic experience in the school. Upper Saddle River, NJ: Prentice-Hall.

Finn, P. (2015). Critical condition: Replacing critical thinking with creativity. Waterloo, ON: Wilfrid Laurier University Press.

Foucault, M. (1969). The Archaeology of Knowledge. New York, NY: Routledge.

Gallaher, Kathleen (2010). Improvisation and education: Learning through? Canadian Theatre Review, 143, 42-46. https://doi.org/10.1353/ctr.0.0036

Gude, O. (2007). Principles of possibility: Considerations for a 21 st-century art \& culture curriculum. Art Education, 60(1), 6-17. https://doi.org/10.1080/00043125.2007.11651621

Henriksen, D. (2018). The 7 transdisciplinary cognitive skills for creative education. Cham, Switzerland: Springer International.

Healy, J. M. (1990). Endangered minds: Why children don't think and what we can do about it. New York, NY: Touchstone.

Holloway, S. M. (2012). Visual literacies and multiliteracies: An ecology arts-based pedagogical model. Language and Literacy, 14(3), 150-168.

Hudson P. B., Hudson S. M., (2007) Examining preservice teachers' preparedness for teaching art. International Journal of Education and the Arts, 8(5), 1-25.

John Grierson and the NFB. (1984). Toronto: ECW Press.

Katz, L. G., \& Chard, S. C. (1989). Engaging children's minds: The project approach. Norwood, NJ: Ablex.

Van Leeuwen, T., \& Jewitt, C. (2001). Handbook of visual analysis. London, UK: Sage.

Mills, K.A. \& Unsworth, L. (2018). iPad animations: Powerful multimodal practices for adolescent literacy and emotional language. Journal of Adolescent \& Adult Literacy, 61(6), 609- 620. https://doi.org/10.1002/jaal.717

Munakata, M., \& Vaidya, A. (2015). Using project- and theme-based learning to encourage creativity in science. Journal of College Science Teaching, 45(2), 48-53.

New Media Consortium. (2005). A global imperative: The report of the 21 st century literacy summit. Retrieved from https://library.educause.edu

Ontario Ministry of Education. (2006). The Ontario curriculum, grades 1-8: Language. Toronto, ON: Queen's Printer for Ontario.

Ontario Ministry of Education. (2010). The Ontario curriculum, grades 1-8: Arts. Toronto, ON: Queen's Printer for Ontario.

Sefton, T., \& Bayley, J. (2010). Stop calling it "PREP": Implementing the new arts curriculum. Ontario Principals' Council Register, 12, 17-20. 
Sefton, T., \& Bayley, J. (2013). The performing professor: Conflicts of identity and work in faculties of education. In S. O’Neill (Ed.), Personhood and music learning: Multidisciplinary perspectives and narrative voices (pp. 319-337). Waterloo, ON: Canadian Music Educators' Association.

Smith, K. (2017). The artists of Crow County. Windsor, ON: Black Moss Press.

Sullivan, G. (2002). A chair raised to the level of a question. Studies in Art Education, 43(3), 195-196. https://doi.org/10.2307/1321084

Tousignant, W., Stanley, D., Salinitri, G., \& Smith, K. (2008). Negotiating shared understandings of our work through a collaborative curriculum: Exploring the experience of creativity in cross discipline visual arts projects. Collected Essays on Learning and Teaching, 1. https://doi.org/10.22329/celt.v1i0.3176

Torrance, E. P., \& Torrance, J. P. (1973). Is creativity teachable? Bloomington, IN: Phi Delta Kappa. 